\title{
Tumor Acidic Microenvironment Targeted Pyropheophorbide a Dimer, an Alternative Strategy for Simultaneous Tumor Fluorescence Imaging and PDT Treatment
}

\author{
Lei Cao, ${ }^{a}$ Shisheng Wang, ${ }^{a}$ Liu Wang, ${ }^{a}$ Xiuhan Guo, ${ }^{a}$ Guangzhe Li, ${ }^{a}$ \\ and Weijie Zhao a,b@ \\ ${ }^{a}$ School of Pharmaceutical Science and Technology, Dalian University of Technology, 116024 Dalian, P.R. China \\ ${ }^{\mathrm{b}}$ State Key Laboratory of Fine Chemicals, Dalian University of Technology, 116024 Dalian, P.R. China \\ ${ }^{\circledR}$ Corresponding authorE-mail: zyzhao@dlut.edu.cn; pharmscizhao@163.com
}

\begin{abstract}
Targeting tumor acidic microenvironment, a cis-aconitate linked pyropheophorbide a dimer 3 was designed and prepared. The observed fluorescence quenching of 3 verified our FRET based molecular design. Acid-dependent cleavage in aqueous solution, singlet oxygen generation, and cytotoxicity against HepG2 cell lines of dimer 3 were investigated. The dimer demonstrated different levels of fluorescence recovery when incubated in acidic aqueous environment as well as effective phototoxicity against HepG2 cells.
\end{abstract}

Keywords: Pyropheophorbide $a$, dimer, FRET, cis-aconitic anhydride, phototoxicity, PDT.

\section{Аимер пирофеофорбида $а$ Аля направленного действия в кислой микросреде опухоли: альтернативная стратегия оАновременной флуоресцентной визуализации опухоли и ФАТ}

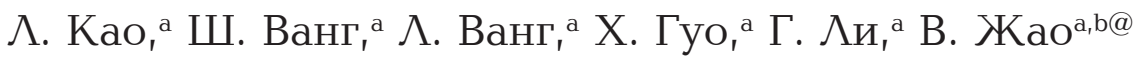 \\ а Школа фармацевтической науки и технологии, Даляньский технологический университет, 116024 Далянь, КНР \\ ' Государственная ключевая лаборатория тонких химических соединений, Даляньский технологический университет, \\ 116024 Далянь, КНР \\ @E-mail: zyzhao@dlut.edu.cn; pharmscizhao@163.com
}

\begin{abstract}
ичс-Аконитат-связанный димер пирофеофорбида а (3), структура которого была разработана на основании резонансного переноса энергии флуоресценции, был синтезирован целенаправленно для использования в качестве фотосенсибилизатора в кислой микросреде опухоли. Для полученного димера было исследовано кислотно-зависимое расщепление в водном растворе, способность к генерации синглетного кислорода и цзитотоксичность в отношении клеточных линий НерG2. Димер показал различные уровни восстановления флуоресценции при инкубациии в кислой водной среде, а также эффективную фототоксичность в отношении клеток Нер 2 .
\end{abstract}

Ключевые слова: Пирофеофорбид $a$, димер, резонансный перенос энергии флуоресценции, цис-аконит ангидрид, фототоксичность, ФДТ.

In recent years, chlorin based photodynamic therapy (PDT) has drawn attentions worldwide, several candidates have shown their potential in treating various malignancies and other diseases in clinical trials, such as NPe6, ${ }^{[1-3]}$ $\mathrm{HPPH}^{[4-5]}$ and Verteporfin. ${ }^{[6-7]}$ Other than treating effect, these chlorins may also serve as imaging agents for photodiagnosis, owing to the ability to emit near-infrared (NIR) fluorescence upon light treatment. ${ }^{[8-11]}$ However, the drawback of in vivo low tumor selective accumulation of nature chlorins resulted in insufficient signal contrast between 
tumor and surrounding tissue, and further limited its clinical application. Therefore, many researchers have paid their attention to tumor microenvironment, especially the representative acidic extracellular fluid. Based on this, various chlorin loaded nanoparticles with acid-sensitive linkers including cis-Aconitate were designed to optimize the fluorescence diagnosis and PDT efficacy of photosensitizers. ${ }^{[12-16]}$ Although some of them did improve the specificity to malignancy by combining the advantage of reversible fluorescence resonance energy transfer (FRET) and the enhanced permeability and retention (EPR) effect, none of the above drug delivery systems has been approved by FDA because of some intrinsic defects such as poor stability and repeatability. On the other hand, to our knowledge, easily obtained acid-sensitive chlorin dimers had been neglected in this field. Therefore, based on the theory of FRET, a chlorin based dimer 3 utilizing acid-cleavable cis-Aconitate as a linker whose acidity-sensitivity had been verified in the above chlorin loaded nanoparticles was designed and synthesized, to investigate the feasibility for tumor imaging and treating upon light irradiation.

In this study, the starting material Pheophorbide $a$ was prepared from Spirulina power produced in Cheng-Hai Lake in Yunnan Province of China, referring to Smith's method. ${ }^{[17]}$ Pyropheophorbide $a$ was obtained by refluxing Pheophorbide $a$ in pyridine and ethylenediamine was employed to link Pyropheophorbide $a$ with cis-Aconitic moieties. Firstly, Boc-ethylenediamine was efficiently intro- duced at the $17^{3}$-carboxylic acid of Pyropheophorbide $a$ with HBTU as coupling reagent, then following deprotection of Boc group with TFA/DCM gave functionalized monomer 2 (Scheme 1). Next, the free carboxylic acid of cis-Aconitic anhydride was converted to active ester with equivalent HBTU, and the result mixture was dropwise added to a solution of alkalized 2 in DMF. Whereafter, concurrent nucleophilic attack of free amino groups to the carbonyl carbons of both active ester and anhydride produced desired dimer 3 in a yield of $31 \%$. Together with the overlap between absorption and emission spectra of $\mathbf{2}$, the appropriate distance between the two chromophores made FRET possible for this synthetic dimer.

The target product $\mathbf{3}$ was characterized by the two sets of chlorin macrocyclic signals in ${ }^{1} \mathrm{H} \mathrm{NMR}$, along with HRMS and typically absorption properties in $\mathrm{MeOH}$ (longer wavelength and enhanced intensity). On account of strong hydrophobicity, week absorption as well as minimal emission of both Pyropheophorbide $a$ and dimer 3 in sole phosphate buffer (PB) were detected (Figure 1). However, the spectral intensity was successfully recovered upon addition of $1 \%$ Cremophor, a commonly used cosolvent. Differing from the precursor Pyropheophorbide $a$, expected fluorescence quenching of dimer 3 was observed in both $\mathrm{MeOH}$ and $\mathrm{PB}$ due to the FRET effect, which suggested week background signal in neutral environment.

To further verify the sensitivity of $\mathbf{3}$ to week acidity, PB solutions (containing $1 \%$ Cremophor) with $\mathrm{pH}=7.4$,
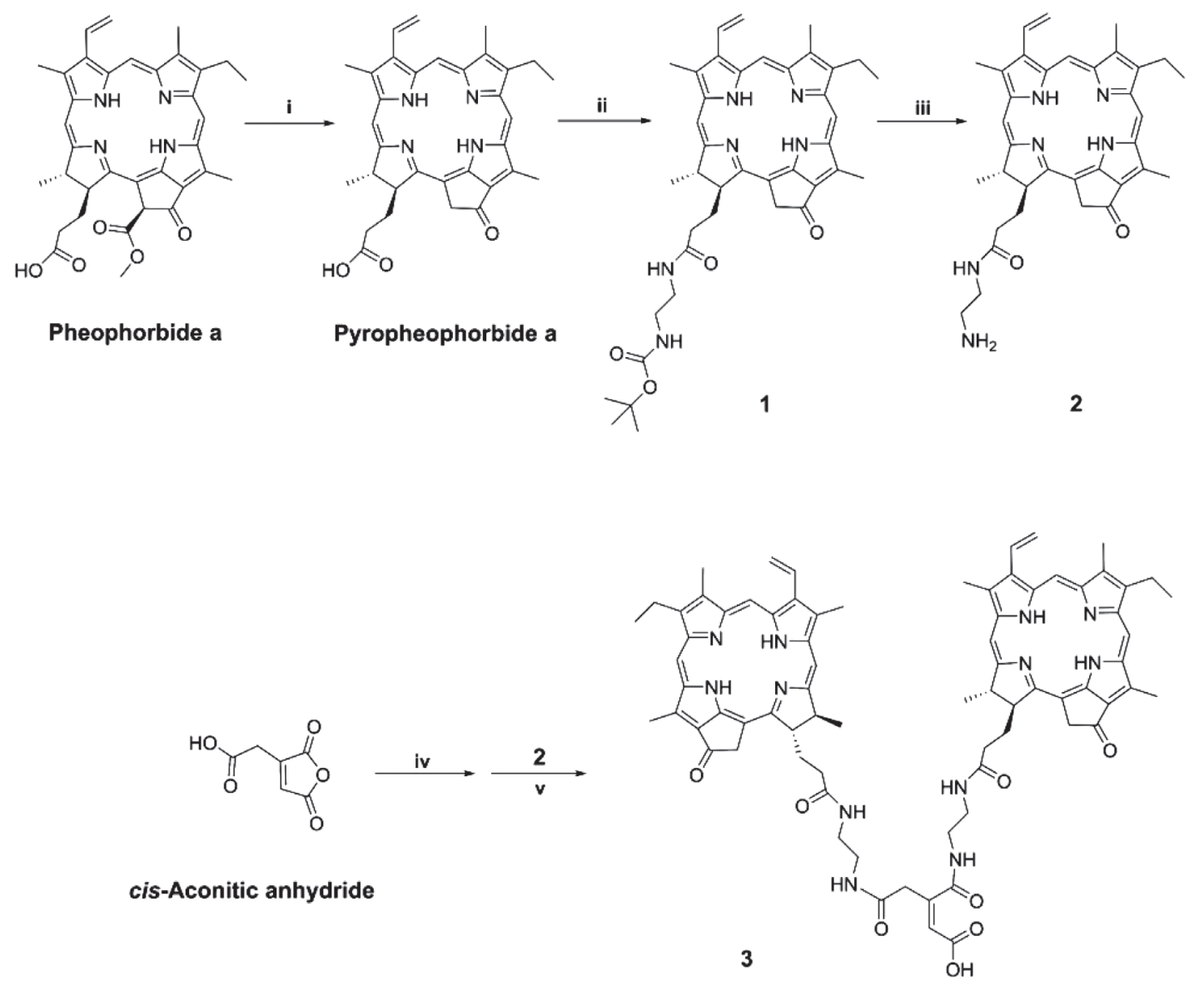

Scheme 1. Synthetic route of dimer 3. Reaction conditions: (i) Pyridine, reflux, 10 h; (ii) $\mathrm{HBTU}_{3} \mathrm{Et}_{3} \mathrm{~N}, \mathrm{DMF}$, r.t., 1 h; $\mathrm{Boc}_{-} \mathrm{EDA}, \mathrm{CH}_{2} \mathrm{Cl}_{2}$, r.t., 2 h; (iii) TFA, Phenol, $\mathrm{CH}_{2} \mathrm{Cl}_{2}$, r.t., 2 h; (iv) $\mathrm{HBTU}$, Et ${ }_{3} \mathrm{~N}, \mathrm{CH}_{3} \mathrm{CN}$, r.t., 2 h; (v) Et ${ }_{3} \mathrm{~N}$, DMF, r.t., 5 h. 

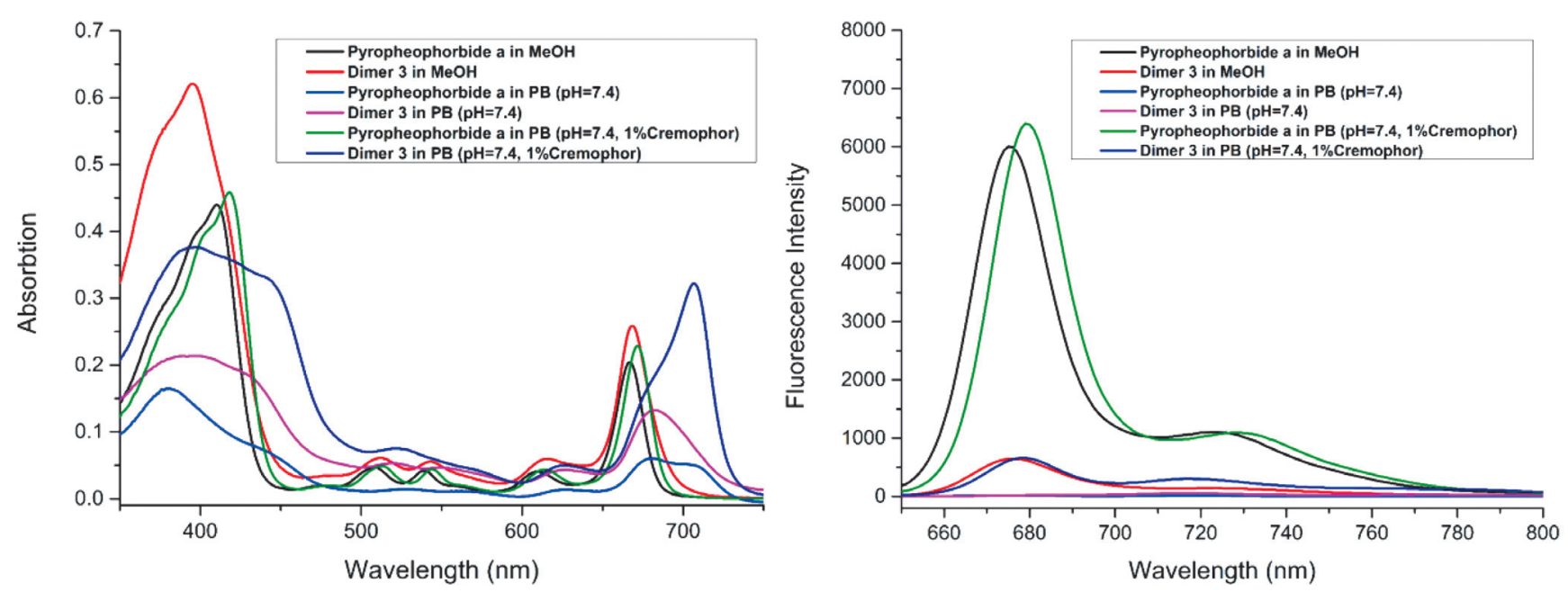

Figure 1. Absorption (left, $5 \mu \mathrm{M}$ ) and emission spectra (right, $1 \mu \mathrm{M}$, excited at $410 \mathrm{~nm}$ ) of Pyropheophorbide $a$ and 3 in different solvent.
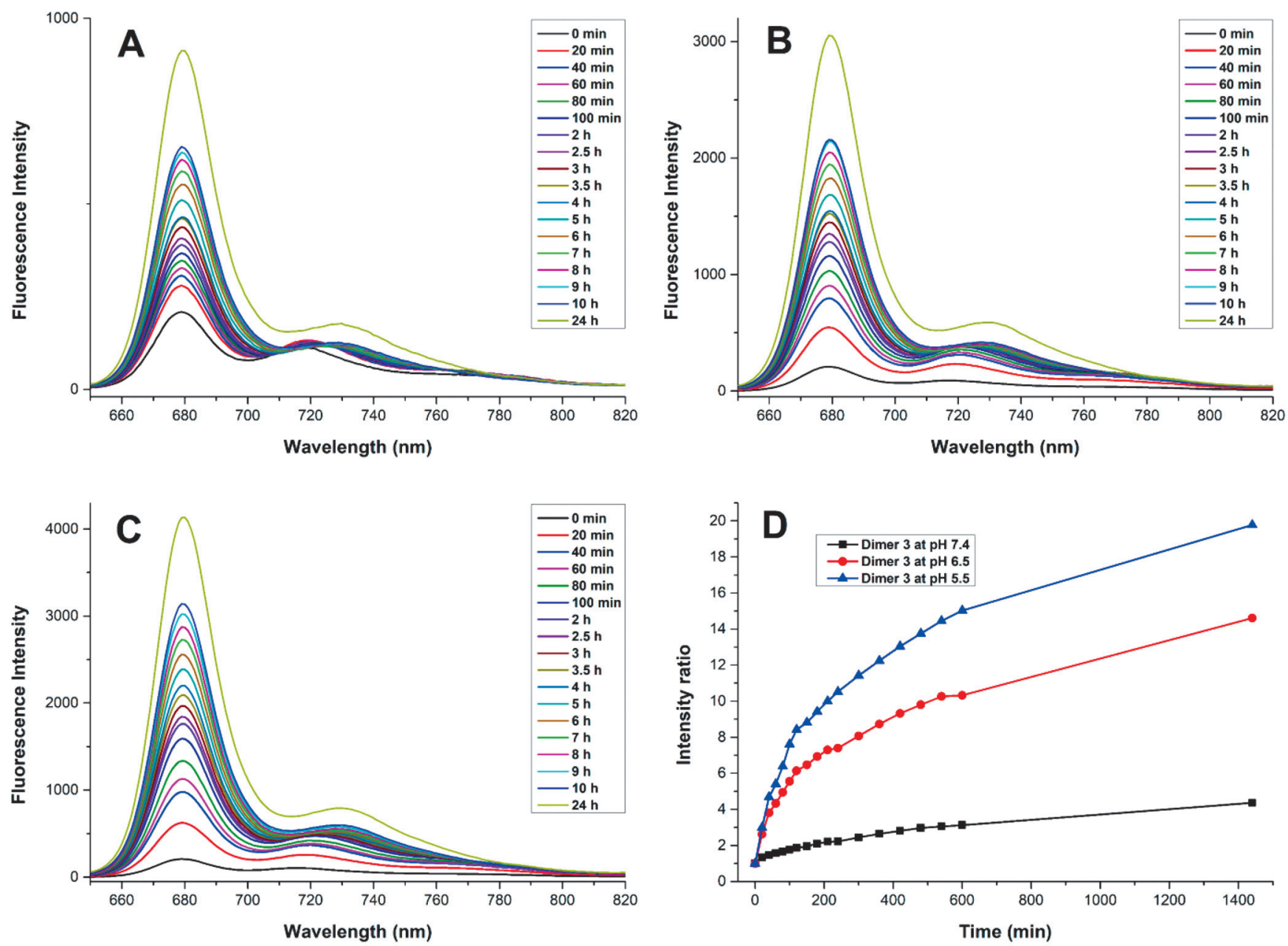

Figure 2. Fluorescence spectra recorded at different time intervals of dimer 3 in PB with $1 \%$ Cremophor (A: $\mathrm{p} H=7.4, \mathrm{~B}: \mathrm{p} H=6.5$, $\mathrm{C}: \mathrm{p} H=5.5)$, and the ratio of fluorescence intensity at time $\mathrm{t}$ to that at time $\mathrm{t}_{0}(\mathrm{D})$.

6.5 or 5.5 were adopted to simulate the microenvironment of normal tissue, tumor tissue and intracellular lysosome, respectively. Dimer 3 was dissolved in the above PB solution $(1 \mu \mathrm{M})$, and the fluorescence spectra were recorded at different time intervals. It turned out that the fluores- cence intensity increased tardily in neutral environment ( $\mathrm{pH}=7.4$ ), indicating relative stability under this condition. But the signals observed in $\mathrm{PB}(\mathrm{p} H=6.5$ and 5.5) dramatically improved in the wake of enhanced acidity, reaching to nearly 15 and 20 folds $24 \mathrm{~h}$ later compared to the initial 

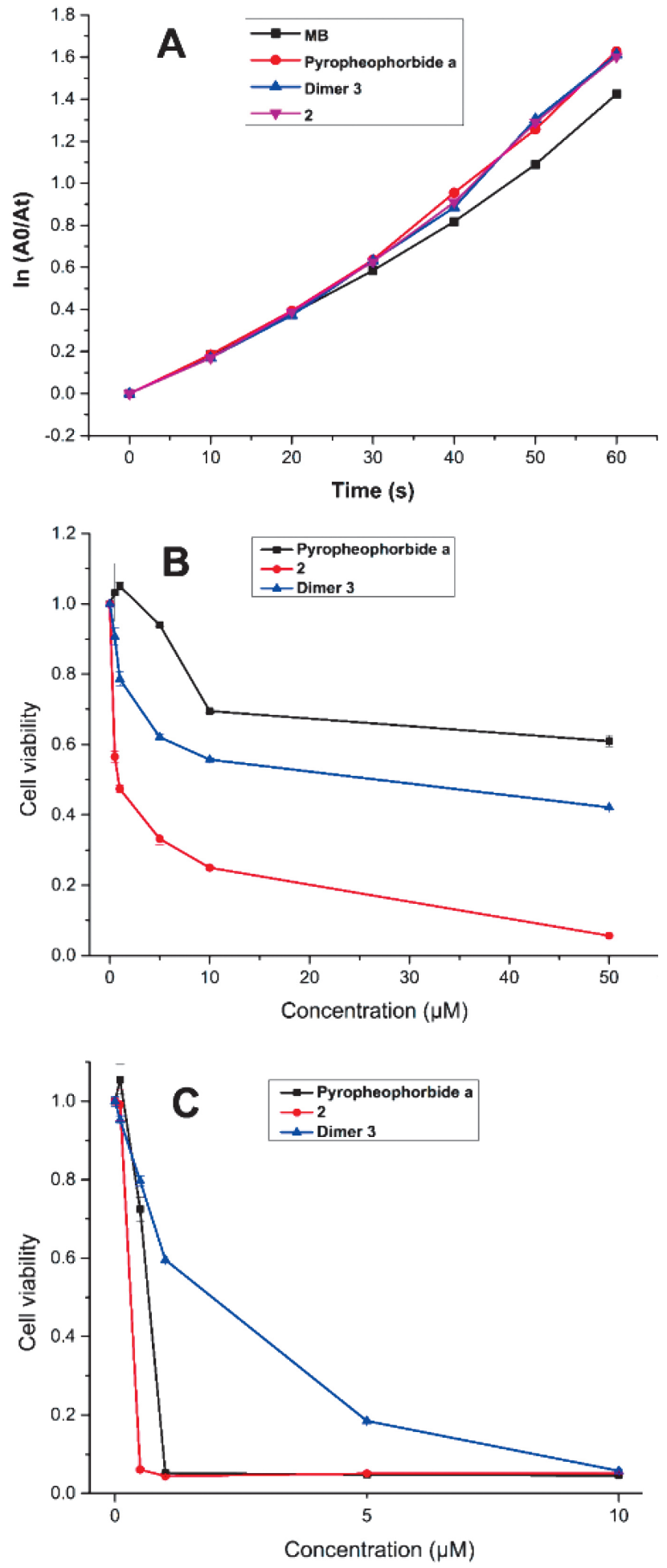

Figure 3. The singlet oxygen quantum yields in DMF (A), dark toxicity (B) and phototoxicity (C) of Pyropheophorbide $a, \mathbf{2}$ and $\mathbf{3}$. data (Figure 2D). Supported by the mass spectrometry (ESI) of the hydrolysis product (found $m / z=577.33$, compound 2), this fluorescence recovery should be attributed to the acidity driven cleavage of the linker, and this energetic response to acidity brought about remarkable signal contrast of neutral $(\mathrm{pH}=7.4)$ and acidulous $(\mathrm{pH}=6.5$ and 5.5) environment. At this point, dimer $\mathbf{3}$ had showed its potential for tumor imaging and even diagnosing.

Since singlet oxygen has been considered as the main cytotoxic substance in PDT process, ${ }^{[18-19]}$ its generation was determined as we previously described. ${ }^{[20]}$ Compared with Pyropheophorbide $a$, dimer 3 and chlorin 2 demonstrated undifferentiated singlet oxygen generation in DMF (Figure 3A), suggesting that photosensitivity of 3 was retained in spite of fluorescence quenching. Meanwhile, the in vitro dark and phototoxicity against HepG2 cell lines were assessed by MTT assay. As shown in Figure 3 and summarized in Table 1, the dimer showed slightly weaker phototoxicity than Pyropheophorbide $a$, which might be ascribed to lower cellular uptake of $\mathbf{3}$ on account of its high molecular weight. What was noteworthy was that the hydrolysis product $\mathbf{2}$ had both stronger dark and phototoxicity than the precursor $\mathbf{3}$. It was very likely that the production of $\mathbf{2}$ was unavoidable during the incubation of HepG2 cell with $\mathbf{3}$, so we suspected that the potent $\mathbf{2}$ could contribute to the efficacy of dimer $\mathbf{3}$ to some extent, and this contribution may increase under in vivo tumor acidic microenvironment, where more 2 would be produced. Unfortunately, in vivo study was infeasible due to the poor water solubility of $\mathbf{3}$, so further optimization of this model in our lab aimed at better hydrophily and also longer absorption wavelength.

In summary, cis-Aconitate linked Pyropheophorbide $a$ dimer $\mathbf{3}$ demonstrated arresting sensitivity to acidity, and the cleavage-driven fluorescence recovery provided impressive signal contrast of different aqueous environment. Taking into account of efficient singlet oxygen production and in vitro phototoxicity at the same time, our work may provide an ideal model to design chlorin based dimers for simultaneous imaging and treating of superficial solid tumor.

\section{Experimental}

All reactions were carried out under nitrogen in air-free solvents and with protection from direct light and monitored by TLC on gel F254 plates. Silica gel (200-300 mesh) was used for column chromatography. ${ }^{1} \mathrm{H}$ NMR and ${ }^{13} \mathrm{C}$ NMR spectra were measured at Bruker Avance $400 \mathrm{MHz}$ spectrometer. Chemical shifts (d) are given in ppm relative to tetramethylsilane (TMS, 0 ppm). HR-MS were obtained on an LTQ Orbitrap XL high resolution mass spectrometer (Thermo Fisher Scientific). Absorption and emission

Table 1. Photo and dark toxicity of chlorins against HepG2 cells evaluated by MTT assay. Data represents the mean \pm standard deviation (SD) of three independent experiments.

\begin{tabular}{ccc}
\hline Compounds & ${\text { Dark } \mathrm{IC}_{50}(\mu \mathrm{M})}$ Photo IC $_{50}(\mu \mathrm{M})$ \\
\hline Pyropheophorbide $a$ & $>50$ & $0.53 \pm 0.01$ \\
$\mathbf{2}$ & $1.50 \pm 0.02$ & $0.27 \pm 0.01$ \\
$\mathbf{3}$ & $18.91 \pm 0.11$ & $1.37 \pm 0.13$ \\
\hline
\end{tabular}


spectra were recorded on an ultraviolet visible spectrophotometer (Lambda 750s, PerkinElmer) and a fluorescence Spectrophotometer (F-7000, Hitachi), respectively. Pheophorbide $a$ was prepared from Spirulina power produced in Cheng-Hai Lake in Yunnan Province of China. Materials obtained from commercial suppliers were used without further purification.

Preparation of Pyropheophorbide a. $600 \mathrm{mg}$ Pheophorbide $a$ was dissolved in $35 \mathrm{~mL}$ pyridine in a $100 \mathrm{~mL}$ round-bottom flask, the solution was heated to reflux under nitrogen atmosphere for $10 \mathrm{~h}$. Then the mixture was concentrated under vacuum to remove the solvent. The residue was purified on a silica gel column eluting with dichloromethane/methanol $=50: 1,25: 1$. Yield: $372 \mathrm{mg}$ (69 \%). HRMS (ESI) $\mathrm{m} / z$ for $\mathrm{C}_{33} \mathrm{H}_{35} \mathrm{~N}_{4} \mathrm{O}_{3}[\mathrm{M}+\mathrm{H}]^{+}$calcd. 535.27, found 535.42; $\mathrm{C}_{33} \mathrm{H}_{33} \mathrm{~N}_{4} \mathrm{O}_{3}[\mathrm{M}-\mathrm{H}]^{-}$calcd. 533.26, found 533.34. ${ }^{1} \mathrm{H}$ NMR (400 MHz, CDCl $) \delta_{\mathrm{H}}$ ppm: $9.31(1 \mathrm{H}, \mathrm{s}), 9.21(1 \mathrm{H}, \mathrm{s}), 8.48$ $(1 \mathrm{H}, \mathrm{s}), 7.87(1 \mathrm{H}, \mathrm{dd} J=17.9,11.5 \mathrm{~Hz}), 6.19(1 \mathrm{H}, \mathrm{d} J=17.9 \mathrm{~Hz}), 6.09$ $(1 \mathrm{H}, \mathrm{d} J=11.5 \mathrm{~Hz}), 5.21(1 \mathrm{H}, \mathrm{d} J=19.8 \mathrm{~Hz}), 5.06(1 \mathrm{H}, \mathrm{d} J=19.8$ $\mathrm{Hz}), 4.43(1 \mathrm{H}, \mathrm{m}), 4.25(1 \mathrm{H}, \mathrm{m}), 3.54(5 \mathrm{H}, \mathrm{m}), 3.33(3 \mathrm{H}, \mathrm{s}), 3.23(1 \mathrm{H}$, d $J=10.1 \mathrm{~Hz}), 3.11(3 \mathrm{H}, \mathrm{s}), 2.60(2 \mathrm{H}, \mathrm{m}), 2.34(1 \mathrm{H}, \mathrm{m}), 2.20(1 \mathrm{H}$, m), $1.78(3 \mathrm{H}, \mathrm{d} J=7.2 \mathrm{~Hz}), 1.61(3 \mathrm{H}, \mathrm{t} J=7.6 \mathrm{~Hz}),-1.77(2 \mathrm{H}, \mathrm{s})$.

Synthesis of $17^{3}$-Boc-ethylenediamine-Pyropheophorbide a 1 . To a solution of $155 \mathrm{mg}$ Pyropheophorbide $a$ in $5 \mathrm{~mL}$ DMF in a $25 \mathrm{~mL}$ round-bottom flask was added $165 \mathrm{mg}$ HBTU and $75 \mu \mathrm{L} \mathrm{Et}_{3} \mathrm{~N}$, the mixture was stirred for $1 \mathrm{~h}$ at room temperature under nitrogen atmosphere then a solution of $137 \mu \mathrm{L}$ Boc-EDA in $5 \mathrm{~mL}$ dichloromethane was added. $2 \mathrm{~h}$ later, the reaction mixture was diluted with dichloromethane and washed with deionized water (5 times) and brine. The organic phase was dried over anhydrous $\mathrm{Na}_{2} \mathrm{SO}_{4}$ and evaporated to dryness and the residue was purified by silica gel column using dichloromethane/methanol $=60: 1,40: 1$ as the eluent. Yield: $170 \mathrm{mg}(87 \%)$. HRMS (ESI) $\mathrm{m} / z$ for $\mathrm{C}_{40} \mathrm{H}_{49} \mathrm{~N}_{6} \mathrm{O}_{4}[\mathrm{M}+\mathrm{H}]^{+}$ calcd. 677.3810, found 677.3815. ${ }^{1} \mathrm{H}$ NMR $\left(400 \mathrm{MHz}, \mathrm{CDCl}_{3}\right) \delta_{\mathrm{H}}$ ppm: $9.15(1 \mathrm{H}, \mathrm{s}), 8.75(1 \mathrm{H}, \mathrm{s}), 8.45(1 \mathrm{H}, \mathrm{s}), 7.81(1 \mathrm{H}, \mathrm{dd} J=17.8$, $11.5 \mathrm{~Hz}), 6.43(1 \mathrm{H}, \mathrm{m}), 6.16(1 \mathrm{H}, \mathrm{d} J=17.8 \mathrm{~Hz}), 6.05(1 \mathrm{H}, \mathrm{d} J=11.5$ $\mathrm{Hz}), 5.17(1 \mathrm{H}, \mathrm{d} J=19.7 \mathrm{~Hz}), 5.01(1 \mathrm{H}, \mathrm{t} J=5.2 \mathrm{~Hz}), 4.93(1 \mathrm{H}, \mathrm{d}$ $J=19.7 \mathrm{~Hz}), 4.44(1 \mathrm{H}, \mathrm{m}), 4.18(1 \mathrm{H}, \mathrm{m}), 3.38(2 \mathrm{H}, \mathrm{m}), 3.30(3 \mathrm{H}, \mathrm{s})$, $3.18(2 \mathrm{H}, \mathrm{m}), 3.08(5 \mathrm{H}, \mathrm{m}), 2.88(3 \mathrm{H}, \mathrm{s}), 2.62(1 \mathrm{H}, \mathrm{m}), 2.30(2 \mathrm{H}, \mathrm{m})$, $2.05(1 \mathrm{H}, \mathrm{m}), 1.73(3 \mathrm{H}, \mathrm{d} J=7.2 \mathrm{~Hz}), 1.47(3 \mathrm{H}, \mathrm{m}), 1.19(9 \mathrm{H}, \mathrm{s}),-1.79$ $(2 \mathrm{H}, \mathrm{s})$.

Synthesis of $17^{3}$-ethylenediamine-Pyropheophorbide a 2 . To a solution of $120 \mathrm{mg} 1 \mathrm{in} 9 \mathrm{~mL}$ dichloromethane in a $50 \mathrm{~mL}$ roundbottom flask was added $16.7 \mathrm{mg}$ phenol and $3 \mathrm{~mL}$ TFA, the mixture was stirred for $2 \mathrm{~h}$ at room temperature under nitrogen atmosphere. The solution was evaporated to dryness and the residue was washed with diethyl ether to remove any phenol and its oxidation product. Yield: $92 \mathrm{mg}\left(90 \%\right.$ ). HRMS (ESI) $\mathrm{m} / \mathrm{z}$ for $\mathrm{C}_{35} \mathrm{H}_{41} \mathrm{~N}_{6} \mathrm{O}_{2}[\mathrm{M}+\mathrm{H}]^{+}$ calcd. 577.3286, found 577.3281. ${ }^{1} \mathrm{H}$ NMR (400 MHz, DMSO$\left.d_{6}\right) \delta_{\mathrm{H}}$ ppm: $9.28(1 \mathrm{H}, \mathrm{s}), 9.07(1 \mathrm{H}, \mathrm{s}), 8.82(1 \mathrm{H}, \mathrm{s}), 8.06(1 \mathrm{H}, \mathrm{t}$ $J=5.8 \mathrm{~Hz}), 8.00(1 \mathrm{H}, \mathrm{dd} J=18.0,11.6 \mathrm{~Hz}), 7.83(2 \mathrm{H}, \mathrm{s}), 6.26(1 \mathrm{H}$, $\mathrm{d} J=18.0 \mathrm{~Hz}), 6.11(1 \mathrm{H}, \mathrm{d} J=11.6 \mathrm{~Hz}), 5.20(1 \mathrm{H}, \mathrm{d} J=20.0 \mathrm{~Hz})$, $5.09(1 \mathrm{H}, \mathrm{d} J=20.0 \mathrm{~Hz}), 4.55(1 \mathrm{H}, \mathrm{m}), 4.29(1 \mathrm{H}, \mathrm{m}), 3.44(3 \mathrm{H}, \mathrm{s})$, $3.40\left(2 \mathrm{H}+\mathrm{H}_{2} \mathrm{O}, \mathrm{m}\right), 3.37(3 \mathrm{H}, \mathrm{s}), 3.29(2 \mathrm{H}, \mathrm{m}), 2.95(3 \mathrm{H}, \mathrm{s}), 2.85$ $(2 \mathrm{H}, \mathrm{m}), 2.63(1 \mathrm{H}, \mathrm{m}), 2.40(1 \mathrm{H}, \mathrm{m}), 2.15(2 \mathrm{H}, \mathrm{m}), 1.83(3 \mathrm{H}, \mathrm{d}$ $J=7.2 \mathrm{~Hz}), 1.48(3 \mathrm{H}, \mathrm{t} J=7.5 \mathrm{~Hz}),-0.13(1 \mathrm{H}, \mathrm{s}),-2.28(1 \mathrm{H}, \mathrm{s})$.

Synthesis of dimer 3. A solution of $12 \mathrm{mg}$ cis-Aconitic anhydride, $31 \mathrm{mg} \mathrm{HBTU}$ and $11 \mu \mathrm{Lt}_{3} \mathrm{~N}$ in $5 \mathrm{~mL}$ acetonitrile in a round-bottom flask was stirred for $2 \mathrm{~h}$ at room temperature under nitrogen atmosphere. The above solution was then added dropwise to a mixture of $89 \mathrm{mg}$ compound 2 and $18 \mu \mathrm{L} \mathrm{Et}{ }_{3} \mathrm{~N}$ in $5 \mathrm{~mL}$ DMF. After stirred for another $5 \mathrm{~h}$, the solution was evaporated and the residue was purified by silica gel column using dichloromethane/methanol $=30: 1,15: 1$ as the eluent. Yield: $60 \mathrm{mg}(31 \%)$. HRMS (ESI) $m / z$ for $\mathrm{C}_{75} \mathrm{H}_{83} \mathrm{~N}_{12} \mathrm{O}_{6}\left[\mathrm{M}+\mathrm{H}-\mathrm{CO}_{2}\right]^{+}$calcd. 1247.6553, found 1247.6565; $\mathrm{C}_{75} \mathrm{H}_{82} \mathrm{~N}_{12} \mathrm{O}_{6} \mathrm{Na}\left[\mathrm{M}+\mathrm{Na}-\mathrm{CO}_{2}\right]^{+}$calcd. 1269.6372, found 1269.6374. ${ }^{1} \mathrm{H}$ NMR $\left(400 \mathrm{MHz}, \mathrm{CDCl}_{3}\right) \delta_{\mathrm{H}} \mathrm{ppm}: 9.09(1 \mathrm{H}$, s), $9.04(1 \mathrm{H}, \mathrm{s}), 8.82(1 \mathrm{H}, \mathrm{s}), 8.73(1 \mathrm{H}, \mathrm{s}), 8.37(1 \mathrm{H}, \mathrm{s}), 8.34(1 \mathrm{H}, \mathrm{s})$, $7.71(2 \mathrm{H}, \mathrm{dd} J=17.7,11.8 \mathrm{~Hz}), 7.18(1 \mathrm{H}, \mathrm{br}), 6.52(2 \mathrm{H}, \mathrm{br}), 6.02$ $(4 \mathrm{H}, \mathrm{m}), 5.65(1 \mathrm{H}, \mathrm{br}), 5.24(1 \mathrm{H}, \mathrm{s}), 4.89(2 \mathrm{H}, \mathrm{m}), 4.66(2 \mathrm{H}, \mathrm{m})$,
$4.37(1 \mathrm{H}, \mathrm{m}), 4.24(1 \mathrm{H}, \mathrm{m}), 3.96(2 \mathrm{H}, \mathrm{m}), 3.33(2 \mathrm{H}, \mathrm{m}), 3.25(4 \mathrm{H}, \mathrm{d}$ $J=14.2 \mathrm{~Hz}), 3.19(3 \mathrm{H}, \mathrm{d} J=5.1 \mathrm{~Hz}), 3.13(3 \mathrm{H}, \mathrm{s}), 3.01(4 \mathrm{H}, \mathrm{s}), 2.98$ $(7 \mathrm{H}, \mathrm{s}), 2.84(3 \mathrm{H}, \mathrm{s}), 2.44(3 \mathrm{H}, \mathrm{d} J=35.5 \mathrm{~Hz}), 2.32-1.86(11 \mathrm{H}, \mathrm{m})$, $1.67(2 \mathrm{H}, \mathrm{s}), 1.61(9 \mathrm{H}, \mathrm{dd} J=13.1,6.9 \mathrm{~Hz}), 1.44(3 \mathrm{H}, \mathrm{t} J=7.5 \mathrm{~Hz})$, $1.38(3 \mathrm{H}, \mathrm{t} J=7.5 \mathrm{~Hz}), 1.25(3 \mathrm{H}, \mathrm{s}),-1.85(1 \mathrm{H}, \mathrm{d} J=3.1 \mathrm{~Hz}),-1.92$ $(1 \mathrm{H}, \mathrm{s}) .{ }^{13} \mathrm{C}$ NMR $(101 \mathrm{MHz}, \mathrm{DMSO}) \delta_{\mathrm{C}} \mathrm{ppm}: 195.5,195.3,172.6$, $172.4,172.0,171.8,170.1,164.9,161.6,161.3,153.9,153.8,149.9$ $149.9,148.0,147.9,146.1,144.5,144.4,140.5,137.1,137.05$, 135.8, 135.7, 135.1, 135.0, 134.7, 134.6, 131.4, 131.4, 129.9, 129.8, 129.1, 129.0, 127.6, 127.5, 122.6, 122.4, 121.4, 105.9, 105.8, 103.7, 96.3, 96.2, 93.6, 93.4, 63.7, 51.6, 51.5, 49.7, 49.6, 47.8, 47.7, 43.3, $38.9,38.8,38.5,33.1,33.0,30.5,23.2,23.0,22.1,18.8,17.7,12.0$, 12.0, 11.8, 11.7, 11.0, 10.9.

Dark toxicity and PDT efficiency against HepG2 cells. HepG2 cells were cultured in DMEM medium supplemented with $10 \%$ (v/v) FBS, $100 \mathrm{IU} / \mathrm{mL}$ penicillin and $100 \mu \mathrm{g} / \mathrm{mL}$ streptomycin and then seeded in 96 -well plates at $5 \times 10^{3}$ cells per well. The cells were cultured in the incubator at $37{ }^{\circ} \mathrm{C}$ with $5 \% \mathrm{CO}_{2}$ for $24 \mathrm{~h}$ prior to start of the experiment. Chlorins were dissolved in DMSO with $10 \%$ Cremophor at $10 \mathrm{mM}$ and diluted with fresh medium to desired concentration. The dark toxicity was assessed with different concentrations (range from 0 to $50 \mu \mathrm{M}$ ). Cells were exposed to graded doses of chlorins for $24 \mathrm{~h}$. The surviving fraction of cells was immediately evaluated using the 3-(4,5-dimethylthiazol-2-yl)2,5-diphenyltetrazolium bromide (MTT) spectrophotometric method. Each experiment was repeated three times. Phototoxicity was evaluated with different concentrations (range from 0 to $10 \mu \mathrm{M}$ ) separately following a similar procedure for dark toxicity. After $24 \mathrm{~h}$ incubation with PSs, the cells were exposed to the LED light of $660 \mathrm{~nm}$ wavelength for $10 \mathrm{~min}$ and the light intensity at the treatment site was $1.4 \mathrm{~J} / \mathrm{cm}^{2}$. The surviving fraction of cells was also evaluated by MTT assay $2 \mathrm{~h}$ after treatment. Each experiment was repeated three times.

Acknowledgements. The authors gratefully acknowledge the support of the State Key Development Program for Basic Research of China (Grant No. 2009CB918501).

\section{References}

1. Kato H., Furukawa K., Sato M., Okunaka T., Kusunoki Y., Kawahara M., Fukuoka M., Miyazawa T., Yana T., Matsui K., Shiraishi T., Horinouchi H. Lung Cancer 2003, 42, 103-111.

2. Spikes J.D., Bommer J.C. J. Photochem. Photobiol., B: Biology 1993, 17, 135-143.

3. Wong T.-W., Aizawa K., Sheyhedin I., Wushur C., Kato H. $J$. Pharm. Sci. 2003, 93, 136-142.

4. Bellnier D.A., Greco W.R., Loewen G.M., Nava H., Oseroff A.R., Pandey R.K., Tsuchida T., Dougherty T.J. Cancer Res. 2003, 63, 1806-1813.

5. Bellnier D.A., Greco W.R., Nava H., Loewen G.M., Oseroff A.R., Dougherty T.J. Cancer Chemoth. Pharm. 2006, 57, $40-45$.

6. Treatment of Age-related Macular Degeneration with Photodynamic Therapy (TAP) Study Group Arch. Ophthalmol. 1999, 117(10), 1329-1345.

7. Brown D.M., Kaiser P.K., Michels M., Soubrane G., Heier J.S., Kim R.Y., Sy J.P., Schneider S. New Engl. J. Med. 2006, $355,1432-1444$

8. Song X., Liang C., Gong H., Chen Q., Wang C., Liu Z. Small 2015, 11, 3932-3941.

9. Huang P., Lin J., Wang X., Wang Z., Zhang C., He M., Wang K., Chen F., Li Z., Shen G., Cui D., Chen X. Adv. Mater. 2012, 24, 5104-5110.

10. Lin J., Wang S., Huang P., Wang Z., Chen S., Niu G., Li W., He J., Cui D., Lu G., Chen X., Nie Z. ACS Nano 2013, 7, $5320-5329$. 
Tumor Acidic Microenvironment Targeted Pyropheophorbide $a$ Dimer

11. Ling D., Park W., Park S.-j., Lu Y., Kim K.S., Hackett M.J., Kim B.H., Yim H., Jeon Y.S., Na K., Hyeon T. J. Am. Chem. Soc. 2014, 136, 5647-5655.

12. Battogtokh G., Ko Y.T. J. Mater. Chem. B 2015, 3, 93499359.

13. Hou W., Zhao X., Qian X., Pan F., Zhang C., Yang Y., de la Fuente J.M., Cui D. Nanoscale 2016, 8, 104-116.

14. Xia F., Hou W., Zhang C., Zhi X., Cheng J., de la Fuente J.M., Song J., Cui D. Acta Biomater. 2018, 68, 308-319.

15. Yao X., Chen X., He C., Chen L., Chen X. J. Mater. Chem. B 2015, 3, 4707-4714.
16. Wang L., Zhu X., Xie C., Ding N., Weng X., Lu W., Wei X., Li C. Chem. Commun. (Camb) 2012, 48, 11677-9.

17. Hargus J.A., Fronczek F.R., Vicente M.G.H., Smith K.M. Photochem. Photobiol. 2007, 83, 1006-1015.

18. Dąbrowski J.M., Krzykawska M., Arnaut L.G., Pereira M.M., Monteiro C.J.P., Simões S., Urbańska K., Stochel G. ChemMedChem 2011, 6, 1715-1726.

19. Ye Y., Wang L.-X., Zhang D.-P., Yan Y.-J., Chen Z.-L. J. Innov. Opt. Heal. Sci. 2015, 08(01), 1540001.

20. Cao L., Guo X., Wang L., Wang S., Li Y., Zhao W. New J. Chem. 2017, 41, 14279-14287.

Received 15.03.2019

Accepted 24.04.2019 